\title{
PENINGKATAN PERANAN PERBANKAN SYARIAH UNTUK PEMBIAYAAN USAHA PERTANIAN
}

\author{
Mhd. Asaad \\ Fakultas Pertanian Universitas Islam Sumatera Utara \\ Jl. Karya Bakti No. 34 Medan, 20143 \\ e-mail: muhammad.asaad62@gmail.com
}

\begin{abstract}
Improving the Role of Syariah Banking for Financing the Agricultural Enterprises. This essay attempts to discuss about the strategy for improving the role played by syariah banking in order to reach financial contribution in agricultural business. In this respect, the author argues that the roles of syariah bank could be maintained so that it can contribute more in to finance agricultural sector in the following strategies: to develop the number of syariah bank offices in agricultural environment, to deliver higher syariah financial contribution to agricultural enterprises, to actively involve in product marketing of syariah banking finance for agricultural enterprises, to exclusively provide finance for syariah bank pertaining to agricultural enterprises, the purpose of which is minimize the potential harvesting failure.
\end{abstract}

Kata Kunci: Perbankan syariah, pembiayaan, usaha pertanian

\section{Pendahuluan}

Islam mewajibkan manusia untuk berusaha agar ia mendapatkan rezeki guna memenuhi kebutuhan kehidupannya. Islam juga mengajarkan kepada manusia bahwa Allah SWT. Maha pemurah sehingga rezeki-Nya sangat luas. Bahkan Allah tidak memberikan rezeki itu kepada kaum muslimin saja, tetapi kepada siapa saja yang bekerja keras. Manusia dapat melakukan pekerjaan apa saja, yang penting tidak melanggar garis-garis yang telah ditentukan-Nya. ${ }^{1}$

Salah satu sektor di mana manusia dapat bekerja untuk mendapat rezeki adalah sektor pertanian. Sektor pertanian masih memainkan peranan sangat strategis dalam perekonomian nasional. Sektor ini tetap menjadi andalan sebagai sumber pendapatan dan mata pencaharian sebagian besar penduduk, penyumbang Produk Domestik Bruto

${ }^{1}$ Muhammad Syafi'i Antonio, Bank Syariah dari Teori ke Praktik, (Jakarta: Gema Insani, 2001), h. 169. 
(PDB), sumber devisa negara, serta pemasok bahan baku sekaligus pasar bagi sektor industri. Bahkan, ada peran sektor pertanian yang tidak mungkin digantikan sektor lain yaitu sebagai sumber bahan pangan. Ada beberapa hal yang menjadi indikator pentingnya sektor ini. Pertama, ditinjau dari besarnya potensi sumber daya alam yang dimiliki. Kedua, kontribusi sektor pertanian terhadap penyerapan angkatan kerja masih sangat besar dan signifikan. Ketiga, menjadi basis pertumbuhan pedesaan. Bahkan tidak hanya itu, sektor pertanian juga berpotensi dalam mengurangi angka kemiskinan. ${ }^{2}$

Setelah tanah, modal adalah nomor dua pentingnya dalam produksi pertanian dalam arti sumbangannya pada nilai produksi. Namun demikian, sektor pertanian masih saja menghadapi permasalahan yang cukup pelik, terutama permodalan. Untuk memulai usaha pertanian diperlukan modal. Berapapun kecilnya usaha pertanian yang dilakukan pasti memerlukan modal. Jika tidak tersedia, peran institusi keuangan menjadi sangat penting karena dapat menyediakan modal bagi orang yang ingin berusaha. ${ }^{3}$

Walaupun demikian, sektor pertanian masih dihadapkan pada beberapa permasalahan, di antaranya kurangnya permodalan petani dan pelaku usaha pertanian seperti telah dijelaskan di atas. Perbankan nasional, secara teoritis memiliki potensi besar sebagai pendukung pembiayaan pertanian, karena secara legal formal merupakan lembaga intermediasi keuangan. Namun, fakta menunjukkan penyaluran kredit perbankan nasional ke sektor pertanian masih sangat kecil yaitu di bawah 6 persen. ${ }^{4}$

Upaya untuk memperoleh modal dapat dilakukan melalui banyak cara seperti dari tabungan sendiri, meminjam dari keluarga ataupun kerabat lainnya. Namun jika tidak tersedia atau karena keperluan modal relatif besar maka peran lembaga keuangan menjadi sangat penting dalam membantu penyediaan modal bagi orang yang ingin berusaha. ${ }^{5}$ Dalam rangka pengelolaan sumber daya pertanian secara efisien, diperlukan seperangkat metode berproduksi (teknologi) penggunaan input serta alat dan mesin pertanian (modal) dalam wadah kelembagaan. Ketersediaan dan aksesibilitas terhadap sumber permodalan oleh pelaku ekonomi adalah sangat penting baik sebagai modal kerja (pembelian input produksi) maupun untuk modal investasi (pengadaan lahan dan pembelian). Beberapa hasil kajian menunjukkan bahwa tingkat sebaran aplikasi suatu teknologi ternyata linear dengan penyebaran ketersediaan permodalan.

Kekurangan modal selalu menjadi masalah klasik bagi sebagian besar pelaku usaha pertanian, termasuk petani. Sementara itu, masih banyak potensi dana di perbankan

${ }^{2}$ Didin Hafidhuddin, Pertanian dengan Prinsip Syariah, http://www.hdrfarm.com/?p=219 diunduh pada tanggal 20 Desember 2010.

${ }^{3}$ Ibid.

${ }^{4}$ Ashari, "Peran Perbankan Nasional dalam Pembiayaan Sektor Pertanian di Indonesia," dalam Forum Penelitian Agro Ekonomi, vol. XXVII, No. 1, (Juli 2009), h. 13-27.

${ }^{5}$ Ashari dan Saptana, "Prospek Pembiayaan Syariah Untuk Sektor Pertanian," dalam Forum Penelitian Agro Ekonomi, vol. XXIII, No. 2 (Desember 2005), h. 135. 
yang belum banyak dimanfaatkan untuk sektor pertanian. Karakteristik sektor pertanian yang berisiko tinggi diduga kuat menjadi penyebab rendahnya minat lembaga pembiayaan untuk mendanai sektor ini. Petani umumnya tidak dapat mengakses lembaga pembiayaan komersial yang menyediakan bunga rendah, seperti BRI Unit Desa, Bank Perkreditan Rakyat, dan koperasi. Hal ini dikarenakan mereka tidak memiliki agunan sertifikat tanah dan pengembalian kredit bulanan sehingga tidak sesuai dengan pola penerimaan usaha tani yang bersifat musiman, dan prosedur pengajuan kredit yang rumit. Petani juga sulit mengakses Koperasi Unit Desa karena kinerjanya lemah, putaran uang lambat, dan modal sulit berkembang. ${ }^{6}$ Sektor pertanian yang merupakan basis pertumbuhan ekonomi pedesaan, sangat strategis dalam meningkatkan pendapatan petani dan mengurangi kemiskinan. Akan tetapi, sampai saat ini para petani masih dihadapkan pada kesulitan pembiayaan untuk pengembangan usahanya.

Sejak dikeluarkannya Undang-Undang Nomor 23 tentang Bank Indonesia sumber pembiayaan dari KLBI dihapuskan. Sumber pembiayaan diarahkan pada sumber pembiayaan komersial, seperti perbankan, asuransi, dan modal ventura. Karena itu, perbankan nasional didorong untuk memberikan perhatian besar terhadap pembiayaan sektor agribisnis ini. Pemerintah telah berusaha mengatasi permasalahan permodalan yang dihadapi usaha pertanian dengan meluncurkan beberapa kredit program untuk sektor pertanian. Kredit program yang memakai sistem bunga menunjukkan hasil yang kurang memuaskan, bahkan menimbulkan permasalahan baru seperti membengkaknya hutang petani serta kredit macet. Salah satu sistem perbankan nasional yang berkembang pesat saat ini adalah perbankan syariah, baik perbankan umum syariah maupun Bank Perkreditan Rakyat Syariah.

Usaha pertanian menghadapi sejumlah kendala dan masalah, baik internal maupun eksternal. Kendala internal pengusaha kecil dan menengah agribisnis, yaitu: (1) Tingkat kemampuan dan profesionalisme SDM di bidang keuangan rendah; (2) Keterbatasan dan penguasaan teknologi; (3) Kelemahan struktur permodalan, keterbatasan akses sumber modal karena diasumsikan beresiko tinggi dan profitabilitas rendah dan tidak memiliki agunan; (4) Kurang mampu memperluas peluang dan akses pasar; (5) Kelemahan di bidang organisasi dan manajemen. Sedangkan kendala eksternal antara lain (1) Kurangnya kepercayaan berbagai pihak terhadap kemampuan usaha kecil; (2) Iklim usaha yang kurang kondusif, karena persaingan yang kuat dari usaha besar; dan (3) Sarana dan prasarana yang kurang memadai. ${ }^{7}$ Berdasarkan hal tersebut perlu dicari model pembiayaan alternatif, salah satu di antaranya adalah dengan skim pembiayaan syariah. Berbeda dengan model kredit, pembiayaan syariah ini bebas bunga, pembagian keuntungan didasarkan

${ }^{6}$ Ade Supriatna, "Pola Pelayanan Pembiayaan Sistem Kredit Mikro Usaha Tani di Tingkat Pedesaan", dalam Jurnal Litbang Pertanian (28 Februari 2009), h. 111.

${ }^{7}$ Agustianto, "Pemberdayaan Agribisnis Melalui Bank Syari'ah", http://agustianto.niriah. com/2008/04/04/pemberdayaan-agribisnis-melalui-bank-syari'ah/ diunduh pada tanggal 26 Desember 2010. 
atas bagi hasil yang dilakukan setelah periode transaksi berakhir. Untuk mendukung implementasinya di sektor pertanian diperlukan keberpihakan pembuat kebijakan serta sosialisasi yang intensif mengenai prinsip-prinsip pembiayaan syariah. ${ }^{8}$

Menurut Bustanul Arifin, ada beberapa persoalan penting dalam pembiayaan pertanian. Pertama, minimnya informasi dan buruknya komunikasi antara sektor pertanian dan lembaga keuangan perbankan dan non-perbankan. Para pelaku bisnis sektor pertanian umumnya kurang aktif untuk menyampaikan peluang bisnis dan prospektif usaha pertanian kepada pelaku usaha di sektor lain, terutama kepada lembaga pembiayaan. Akibatnya, sektor pertanian menjadi kurang atraktif bagi lembaga pembiayaan, terutama sektor perbankan. Kedua, sektor perbankan tidak memiliki pemahaman yang lengkap tentang prospek sektor pertanian. Mereka hanya mengetahui dari persepsi atau literatur ekonomi pembangunan kadaluwarsa, bahwa pertanian itu sebagai suatu sektor usaha sangat beresiko, tergantung musim, jaminan harga yang tidak pasti, dan sebagainya. ${ }^{9}$ Proporsi perbankan syariah dalam penyaluran pembiayaan baru mencapai sekitar dua persen dari angka penyaluran kredit/pembiayaan secara nasional. Ditargetkan tahun 2008 perbankan syariah didorong dapat menyalurkan kredit hingga mencapai pangsa lima persen. Hal ini menjadi tantangan berat sekaligus peluang dalam mendorong pengembangan perbankan syariah, terutama untuk pembiayaan sektor pertanian.

\section{Landasan Hukum Bank Syariah}

Sistem Perbankan Syariah mulai dilaksanakan di Indonesia pada tahun 1992, dengan digulirkannya UU Nomor 7/1992 yang memungkinkan bank menjalankan operasional bisnisnya dengan sistem bagi hasil. Pada tahun yang sama, lahir bank syariah pertama di Indonesia yaitu Bank Syariah Muamalat Indonesia (BMI). Pada tahun 1998 lahir pula UU Nomor 10 tahun 1998 tentang perubahan UU Nomor 7 tahun 1992, tentang Perbankan. Menurut UU Nomor 10 tahun 1998 disebutkan bahwa Bank Umum yang melaksanakan kegiatan usaha berdasarkan prinsip syariah yang dalam kegiatannya memberikan jasa dalam lalu lintas pembayaran. Dalam menjalankan aktivitasnya Bank Syariah menganut prinsip-prinsip sebagai berikut yaitu (1) Keadilan, (2) Kesederajatan dan (3) Ketenteraman. ${ }^{10}$

Asas dari kegiatan usaha perbankan syariah adalah prinsip syariah, demokrasi ekonomi dan prinsip kehati-hatian. Maksud berasaskan prinsip syariah adalah kegiatan usaha yang tidak mengandung riba, maisir, gharar, objek haram dan menimbulkan kezaliman.

${ }^{8}$ Ashari dan Saptana, Prospek Pembiayaan, h. 132.

${ }^{9}$ Bustanul Arifin, 2006. "Mengatasi Kesulitan Pembiayaan Sektor Pertanian", http://barifin. multiply.com/journal/item/17?\&item_id=17\&view:replies=reverse diunduh pada tanggal 20 Desember 2010.

${ }^{10}$ Muhammad, Bank Syari'ah Problema dan Prospek Perkembangan di Indonesia (Yogyakarta: Graha Ilmu, 2005), h. 78-80. 
Sedangkan yang dimaksud dengan berasaskan demokrasi ekonomi adalah kegiatan usaha yang mengandung nilai keadilan, kebersamaan, pemerataan dan kemanfaatan.

\section{Prinsip dan Produk Pembiayaan Syariah}

Manusia bisa melakukan aktivitas produksi seperti pertanian, perkebunan, peternakan, pengolahan makanan dan minuman. Ia juga dapat melakukan aktivitas distribusi seperti perdagangan atau dalam bidang jasa seperti transportasi dan kesehatan. ${ }^{11}$ Peran institusi keuangan dalam hal ini menjadi sangat penting, karena dapat menyediakan modal bagi orang yang ingin berusaha. Dalam Islam, hubungan pinjam meminjam tidak dilarang, bahkan dianjurkan agar terjadi hubungan saling menguntungkan, yang pada gilirannya berakibat kepada hubungan persaudaraan. Hal yang perlu diperhatikan adalah apabila hubungan itu tidak mengikuti aturan yang diajarkan oleh Islam. Karena itu, pihak-pihak yang berhubungan harus mengikuti etika yang digariskan oleh Islam.

Prinsip pembiayaan syariah yang mendasar adalah keadilan, pembiayaan saling menguntungkan baik pihak yang menggunakan dana maupun pihak yang menyediakan dana, dan kepercayaan. Hal ini merupakan landasan dalam menentukan persetujuan pembiayaan maupun dalam menghitung margin keuntungan maupun bagi hasil yang menyertai pembiayaan tersebut.

Perbankan Syariah atau Perbankan Islam adalah suatu sistem perbankan yang dikembangkan berdasarkan syariah Islam. Usaha pembentukan sistem ini didasarkan pada larangan dalam Islam untuk memungut maupun meminjam dengan bunga atau yang disebut dengan riba. Serta larangan investasi untuk usaha-usaha yang dikategorikan haram seperti usaha yang berkaitan dengan produksi makanan dan minuman haram, serta usaha media yang tidak Islami, di mana hal ini tidak dapat dijamin oleh sistem perbankan konvensional.

Usaha pertanian yang penuh resiko membutuhkan pembiayaan yang lebih fleksibel terutama dalam pembagian keuntungan atau kerugian dalam berusaha. Selain sistem bagi hasil, lembaga keuangan syariah juga menawarkan produk dengan sistem jual beli, sewa maupun gadai. Produk pembiayaan syariah yang dapat diterapkan pada usaha agribisnis antara lain mudharabah, musyârakah, muzâra'ah, musaqoh, bai' murâbahah, bai' istishna, bai' al-salâm, dan gadai (rahn). ${ }^{12}$ Berdasarkan pembiayaan usaha pertanian yang sesuai dengan prinsip dasar pembiayaan syariah antara lain bagi hasil (profit sharing), dan jual beli (sale and payment sale). Jenis-jenis pembiayaan bagi hasil yang dapat diterapkan pada usaha pertanian:

1. Al-Musyarâkah (Partnership, Project Financing and Participation) adalah penanaman

${ }^{11}$ Antonio, Bank Syariah, h. 169.

${ }^{12}$ Ashari dan Saptana, Prospek Pembiayaan, h. 138. 
dana dari shahib al-mâl (pemilik modal) untuk mencampurkan dana/modal mereka pada suatu usaha tertentu, dengan pembagian keuntungan berdasarkan nisbah yang telah disepakati sebelumnya, sedangkan kerugian ditanggung semua shahib al-mâl berdasarkan bagian dana/modal masing-masing.

2. Al-Mudharabah (Trust Financing, Trust Investment) adalah akad kerjasama antara dua pihak di mana pihak shahib al-mâl menyediakan modal dan pihak mudharib menjadi pengelola. Keuntungan usaha dibagi berdasarkan nisbah sesuai dengan kesepakatan. Pembagian nisbah dapat menggunakan metode bagi untung dan rugi (profit and loss sharing) atau metode bagi pendapatan (revenue sharing).

3. Al-Muzâra'ah (Harverst-Yield Profit Sharing) adalah kerja sama pengolahan pertanian antara pemilik lahan dan penggarap, di mana pemilik lahan memberikan lahan pertanian kepada penggarap untuk ditanami dan dipelihara dengan imbalan bagian tertentu dari hasil panen. Biasanya diterapkan untuk pembiayaan produk pertanian (agrobased industries) atau produk-produk yang terstandarisasi. ${ }^{13}$

4. Al-Musaqah (Plantation Management Fee Based on Certain Portion of Yield) adalah bentuk sederhana dari al-Muzâra'ah di mana penggarap hanya bertanggungjawab atas penyiraman dan pemeliharaan. Sebagai imbalan, si penggarap berhak atas nisbah tertentu dari hasil panen. ${ }^{14}$

5. Bai' al-Murâbahah (differed payment sale) adalah jual beli barang pada harga asal dengan tambahan keuntungan yang disepakati. Lembaga pembiayaan akan membelikan suatu barang yang dibutuhkan nasabah, kemudian nasabah menerima tersebut dan membayar sesuai dengan kemampuan (besarnya berdasarkan kesepakatan). Dalam sektor pertanian, dapat dimanfaatkan untuk pembelian alat dan mesin pertanian, seperti hand tractor, pompa air, dan powerthresher, rice milling unit.

6. Bai'al-Salâm (in front payment sale) merupakan jual beli dengan ketentuan si pembeli membayar saat ini, sedangkan barang akan diterimanya di masa mendatang. Bai' al-salâm berbeda dengan praktik ijon yang telah dikenal dan dipraktikkan masyarakat pedesaan hingga saat ini. Dalam sistem ijon sama sekali tidak jelas kuantitas barang

${ }^{13}$ Diriwayatkan dari Ibnu Umar bahwa Rasulullah SAW., pernah memberikan tanah Khaibar kepada penduduknya (waktu itu mereka masih Yahudi) untuk digarap dengan imbalan hasil buah-buahan dan tanaman. Diriwayatkan oleh Bukhari dari Jabir yang mengatakan bahwa bangsa Arab senantiasa mengolah tanahnya secara muzara'ah dengan rasio bagi hasil 1/3:2/ 3; 1/4:2/4; 1/2:1/2 maka Rasulullah pun bersabda, "Hendaklah menanami atau menyerahkannya untuk digarap. Barang siapa tidak melakukan salah satu dari keduanya, tahanlah tanahnya", lihat Muhammad Syafi'i Antonio, Bank Syariah dari Teori ke Praktik (Jakarta: Gema Insani, 2001), h. 99.

${ }^{14}$ Ibnu Umar berkata bahwa Rasulullah SAW., pernah memberikan tanah dan tanaman kurma di Khaibar kepada Yahudi Khaibar untuk dipelihara dengan mempergunakan peralatan dan dana mereka. Sebagai imbalan, mereka memperoleh persentase tertentu dari hasil panen. 
yang diperjualbelikan serta sangat spekulatif. Pada bai' al-salâm disyaratkan harus jelas kuantitas, kualitas barang serta waktu pembayarannya. ${ }^{15}$

7. Bai' al-Istishna (Purchase by order or manufactured) disebut juga sebagai piutang istishna, adalah fasilitas penyaluran dana untuk pengadaan barang investasi berdasarkan pesanan. Dalam transaksi, bai' al-istishna ini ada kontrak antara pembeli dan pembuat barang, di mana pembuat barang menerima pesanan dari pembeli. Kedua belah pihak bersepakat atas harga serta sistem pembayaran, apakah dilakukan dengan kontan, melalui cicilan, atau ditangguhkan pada masa mendatang.

8. Al-Rahn (mortage) adalah menahan salah satu harta milik si peminjam sebagai jaminan atas peminjaman yang diterimanya. Barang yang ditahan tersebut harus memiliki nilai ekonomis, dan pihak yang menahan memperoleh jaminan untuk dapat mengambil kembali seluruh atau sebagian piutangnya. Praktik gadai atau rahn sudah umum dijumpai di pedesaan.

Selanjutnya berdasarkan Undang-Undang Nomor 21 tahun 2008 Tentang Perbankan Syariah dijelaskan bahwa prinsip syariah memiliki dua prinsip yaitu (1) Prinsip syariah adalah prinsip hukum Islam, dan (2) Penetapan pihak dan lembaga berwenang mengeluarkan fatwa yang menjadi dasar prinsip syariah. Pembiayaan dapat berupa transaksi bagi hasil, transaksi sewa menyewa, transaksi jual beli, transaksi pinjam meminjam dan transaksi sewa menyewa jasa (multi jasa).

Prinsip syariah adalah aturan perjanjian berdasarkan hukum Islam antara bank dan pihak lain untuk penyimpanan dana dan/atau pembiayaan kegiatan usaha, atau kegiatan lainnya yang sesuai dengan syariah. Beberapa prinsip/hukum yang dianut oleh sistem perbankan syariah antara lain (1) Pembayaran terhadap pinjaman dengan nilai yang berbeda dari nilai pinjaman dengan nilai ditentukan sebelumnya tidak diperbolehkan; (2) Pemberi dana harus turut berbagi keuntungan dan kerugian sebagai akibat hasil usaha institusi yang meminjam dana; (3) Islam tidak memperbolehkan uang menghasilkan uang. Uang hanya merupakan media pertukaran dan bukan komoditas karena tidak memiliki nilai intrinsik; (4) Unsur ketidakpastian, spekulasi atau gharar tidak diperkenankan. Kedua belah pihak harus mengetahui dengan baik hasil yang akan mereka peroleh dari sebuah transaksi; dan (5) Investasi hanya boleh diberikan pada usaha-usaha yang tidak diharamkan dalam syariat. ${ }^{16}$

${ }^{15}$ Adanya kerelaan yang utuh antara kedua belah pihak. Hal ini terutama dalam kesepakatan harga. Allah SWT., berfirman: "Kecuali dengan jalan perniagaan yang berlaku dengan suka sama suka di antara kalian", (al-Nisaa': 29) lihat; Muhammad Syafi'i Antonio, Bank Syariah dari Teori ke Praktik (Jakarta: Gema Insani, 2001), h. 111.

16 "Hai orang-orang yang beriman, janganlah kamu makan harta sesamamu dengan jalan batil, kecuali dengan perdagangan yang dilakukan dengan suka sama suka di antara kamu", (al-Nisa: 29). Pemahaman terhadap ayat ini adalah bahwa kepemilikan pribadi harus berperan sebagai kapital produktif yang akan meningkatkan besaran produksi nasional supaya harta itu jangan berputar di sekitar orang-orang kaya saja. 


\section{Prinsip Pembiayaan Syariah untuk Usaha Pertanian}

Secara teoretis, ada tiga hal yang menjadi ciri pembiayaan syariah, yaitu (1) Bebas bunga (interest free), (2) Bagi hasil dan resiko (profit loss sharing), dan (3) Perhitungan bagi hasil dilakukan pada saat transaksi berakhir. Hal ini berarti pembagian hasil dilakukan setelah ada keuntungan riil, bukan berdasar pada asumsi bahwa besarnya keuntungan usaha yang akan diperoleh di atas bunga kredit. Penggunaan kata pinjam-meminjam dalam perbankan syariah kurang tepat digunakan disebabkan dua hal. Pertama, pinjaman merupakan salah satu metode hubungan finansial dalam Islam. Masih banyak metode yang diajarkan oleh syariah selain pinjaman, seperti jual beli, bagi hasil, sewa, dan sebagainya. Kedua, dalam Islam pinjam-meminjam adalah akad sosial, bukan akad komersial. Artinya, bila seseorang meminjam sesuatu, ia tidak boleh disyaratkan untuk memberikan tambahan atas pokok pinjamannya. ${ }^{17}$

Salah satu pembiayaan perbankan syariah yang sering diimplementasikan dengan usaha pertanian yaitu Bai' al-salâm. Konsep Bai' al-salâm adalah akad jual beli di mana pembeli membayar uang sebesar harga atas barang yang telah disebutkan spesifikasinya, sedangkan barang yang diperjual belikan itu akan diserahkan kemudian pada tanggal yang disepakati. Bai' al-salâm biasanya dilakukan untuk produk-produk pertanian jangka pendek. Adapun contoh perhitungan praktis dari pembiayaan Bai' al-salâm ini adalah: Seorang petani memerlukan dana mengolah sawahnya seluas satu hektar. Bank melakukan akad Bai' al-salâm dengan petani, di mana bank akan membeli gabah yang dihasilkan petani. Dalam terminologi pertanian keadaan ini disebut bayar setelah panen. Pada saat jatuh tempo, petani harus menyetorkan gabah yang dimaksud kepada bank. Jika bank tidak membutuhkan gabah untuk keperluannya sendiri, bank dapat menjualnya kepada pihak lain atau meminta petani mencarikan pembelinya dengan harga yang telah disepakati dalam akad atau dapat lebih tinggi.

Pola pembiayaan syariah sangat prospektif untuk diimplementasikan di sektor pertanian. Hal ini didukung dengan karakteristik dari perbankan syariah maupun sifat sektor dan pelaku usaha pertanian yang bisa saling bersinergi. Di antara karakteristik perbankan syariah yang kondusif untuk sektor pertanian adalah: (1) Spirit pembiayaan syariah sesuai dengan bisnis pertanian, (2) Komitmen yang kuat untuk pembiayaan UMKM, (3) Nilai FDR yang relatif tinggi, dan (4) Sifat usaha yang universal. Pada sektor pertanian dikenal sistem maro, mertelu, marapat, dan paroan. Sistem bagi hasil pertanian, terutama untuk tanaman padi berlangsung antara penggarap dan pemilik modal lahan dengan proporsi bagi hasil yang relatif beragam. Skema kerja sama ini dalam fiqih dikenal dengan istilah muzarariah, musaqah dan mukhabarah.

${ }^{17}$ Hal ini didasarkan pada hadis Nabi SAW., yang mengatakan bahwa setiap pinjaman yang menghasilkan manfaat adalah riba, sedangkan para ulama sepakat bahwa riba itu haram. Karena itu, dalam perbankan syariah, pinjaman tidak disebut kredit, tetapi pembiayaan. 
Pola pembiayaan syariah mempunyai karakteristik yang lebih cocok dengan komoditi yang dibudidayakan oleh petani. Hal ini disebabkan: (1) Bank Islam tidak mengenal adanya perhitungan bunga tetapi menggunakan prinsip bagi hasil dan pengambilan keuntungan secara jual beli, (2) Prinsip bagi hasil, besarnya pembagian porsi keuntungan antara pemilik dana atau bank dan pengelola usaha atau petani diserahkan kepada kedua belah pihak tersebut disesuaikan dengan masa panen, (3) Usaha pertanian yang kecil pendapatannya, nisbah yang disepakati tidak sama dengan usaha yang lebih besar pendapatannya, mengingat setiap komoditi usaha pertanian memiliki tingkat pendapatan berbeda dan masa panen yang berbeda pula, (4) Petani tidak dibebani dangan bunga pinjaman melainkan pengembaliannya secara otomatis disesuaikan dengan masa panen.

\section{Kekuatan dan Kelemahan Perbankan Syariah untuk Pembiayaan Usaha Pertanian}

Adanya Undang-Undang Nomor 10 Tahun 1998 dan peraturan pendukungnya, yang memberi peluang sangat besar bagi perkembangan Perbankan Syariah di Indonesia, kuatnya dukungan pemerintah dalam hal ini Bank Indonesia, bagi pendirian bank-bank syariah, dan proses penyehatan industri perbankan nasional merupakan momentum yang lebih baik bagi lahirnya generasi kedua Perbankan Syariah di Indonesia. Agar lebih berhasil menjadi pendorong terwujudnya perekonomian Indonesia yang kokoh, bank syariah harus menjadi perekat nasionalisme baru, berpihak pada ekonomi kerakyatan, beroperasi secara transparan, berfungsi sebagai pendorong peningkatan efisiensi mobilisasi dana masyarakat, dan menjadi contoh teladan bagi praktik usaha berlandaskan moral dan etika Islam. ${ }^{18}$

Hasil survei Bank Indonesia di beberapa propinsi di Jawa dan Sumatera pada tahun 2000-2001 menunjukkan bahwa antusiasme masyarakat terhadap perbankan syariah cukup tinggi. Berdasarkan hasil survei ini disimpulkan bahwa nasabah potensial bank syariah mencapai 78\%, dengan perincian 11\% merupakan syariah loyalis, yaitu nasabah yang akan beralih ke bank syariah terdekat serta 67\% merupakan floating customer yaitu nasabah yang akan beralih ke bank syariah jika infrastruktur dan pelayanan yang ditawarkan perbankan syariah tidak berbeda dengan bank konvensional. Di luar 78\% merupakan konvensional loyalis yang tidak terlalu terpengaruh dengan keberadaan bank syariah. ${ }^{19}$

Kehadiran lembaga perbankan syariah sangat tepat untuk mengembangkan sektor

\footnotetext{
${ }^{18}$ Neuneung Ratna Hayati, "Perbankan Syariah Nasional: Peranan, Peluang, Permasalahan, Prospek serta Strategi Pengembangannya", dalam Jurnal Bisnis, Manajemen dan Ekonomi, vol. VII, No. 3 (Februari 2006), h. 871.

${ }^{19}$ Malia Rochma, Perbankan Syariah: Peluang dan Strategi Pengembangan, http://ucupneptune. blogspot.com/2007/11/perbankan-syariah-peluang-dan strategi.html diunduh pada tanggal 24 Desember 2010.
} 
agribisnis atau usaha pertanian, baik bank umum syari'ah maupun Bank Perkreditan Rakyat Syari'ah. Hal ini dikarenakan, bank syariah menggunakan skema bagi hasil (mudharabah, muzâra'ah, dan musyârakah), di samping skema lainnya seperti jual beli salam dan murâbahah. Konsep bagi hasil sebenarnya bukan transaksi baru dalam masyarakat Indonesia. Tradisi ini telah lama dikenal dalam berbagai kegiatan ekonomi. Pada sektor pertanian dikenal sistem maro, mertelu, marapat, dan paroan. Sistem bagi hasil pertanian, terutama untuk tanaman padi berlangsung antara penggarap dan pemilik modal lahan dengan proporsi bagi hasil yang relatif beragam. Skema kerja sama ini dalam fikih dikenal dengan istilah muzâra'ah, musaqah dan mukhabarah. Pada sektor kelautan juga praktik bagi hasil telah lama dipraktikkan antara nelayan dan pemilik boat/perahu. Sistem ini tampaknya lebih cocok, karena hasil ikan yang akan diperoleh para nelayan tidak dapat diperkirakan, sehingga sistem bagi hasil ini lebih adil. Jika diidentifikasi ada beberapa permasalahan yang masih dihadapi dalam proses pengembangan bank syariah saat ini, yakni: ${ }^{20}$

1. Pemahaman masyarakat yang belum tepat terhadap kegiatan operasional bank syariah.

2. Peraturan Perbankan yang berlaku belum sepenuhnya mengakomodasi operasional bank syariah.

3. Jaringan kantor bank syariah yang belum luas.

4. Sumber daya manusia yang memiliki keahlian bank syariah masih sedikit.

Beberapa masalah lainnya yang menyebabkan masih kurangnya peranan bank syariah dalam pembiayaan usaha pertanian antara lain:

1. Pembiayaan yang diberikan bank syariah kepada usaha pertanian masih lebih sedikit dibandingkan dengan usaha lain, beberapa faktor penyebabnya antara lain: Karakter dari petani yang memiliki pola hidup yang cenderung konsumtif, sehingga mudah tertipu dengan pihak-pihak seperti tengkulak yang akhirnya mengakibatkan petani hidup dalam kemiskinan.

2. Petani mengelola usaha taninya dengan cara yang tidak profesional dikarenakan kurangnya kemampuan petani untuk menata usahanya dengan baik, juga kurangnya perhatian pemerintah terhadap usaha pertanian yang merupakan dasar dari segala jenis usaha lainnya termasuk dalam hal kepastian harga.

3. Petani sulit untuk mendapatkan legalitas usahanya sehingga tidak mendapat kepercayaan dari perbankan syariah untuk memberikan pembiayaan syariah.

4. Kurangnya pengetahuan petani terhadap perbankan syariah dikarenakan lokasi perbankan syariah yang cenderung jauh dari usaha pertanian, sedikitnya pengenalan yang dilaksanakan perbankan syariah terhadap usaha pertanian dan sifat petani yang cenderung sulit menerima perubahan.

Selanjutnya, setidaknya ada tiga sifat yang melekat pada skim kredit pertanian

${ }^{20}$ Antonio, Bank Syariah, h. 224-226. 
yang berpeluang menimbulkan ketidakefektifan. Pertama, kredit selalu berbasis bunga tetap (fix interest). Jika petani gagal dalam usaha taninya, baik karena gagal panen maupun rendahnya harga pasar, mereka tidak akan mampu membayar pinjaman sehingga dapat terjerat hutang yang semakin besar karena prinsip bunga berbunga. Kedua, terdapat kesenjangan dalam ruang usaha antara peminjam (debitor) dan pemberi pinjaman (kreditor). Pihak debitor murni berusaha di sektor riil, sementara kreditor hanya bergerak di sektor moneter. Konsekuensinya, resiko kegagalan usaha umumnya hanya akan dibebankan kepada debitor, sementara kreditor tetap mendapatkan keuntungan sebesar tingkat suku bunga yang ditetapkan. Ketiga, sistem pembiayaan pertanian selama ini diintegrasikan dengan pembiayaan nonpertanian. Sistem penghitungan usaha pada sektor nonpertanian, terutama industri dan jasa, jika diterapkan untuk usaha pertanian cenderung over estimate. Apabila dipaksakan hal ini akan membuat usaha pertanian tidak akan mendapat dukungan kredit dalam jumlah sesuai dengan kebutuhan. ${ }^{21}$

Pembiayaan perbankan syariah telah tampak dalam sistem keuangan syariah di Indonesia yang masih dalam tahap pertumbuhan (infant industry) yang masih banyak memiliki kelemahan di berbagai hal antara lain: kelemahan-kelemahan operasional, seperti masih rendahnya pembiayaan berbasis bagi hasil (equity based), seperti mudharabah dan musyârakah (bagi hasil), dan masih mendominasinya pembiayaan berbasis hutang (debt based), seperti murâbahah (jual-beli), yang membuat perbankan syariah mirip sifatnya dengan perbankan konvensional. ${ }^{22}$

\section{Peluang dan Tantangan Perbankan Syariah untuk Pembiayaan Usaha Pertanian}

Tidak dipungkiri bahwa peranan bank syariah untuk pembiayaan usaha pertanian akan menghadapi beberapa tantangan dalam implementasinya. Tantangan tersebut dapat bersifat internal (karakteristik sektor pertanian) maupun eksternal. Sektor pertanian yang penuh resiko karena sangat bergantung pada alam akan membuat investor ekstra hati-hati untuk membiayai sektor ini. Usaha pertanian yang umumnya kecil-kecil dan tersebar juga memerlukan kepiawaian tersendiri agar biaya per unit untuk menggarap sektor ini tidak membengkak. Tantangan eksternalnya lebih banyak terkait dengan keberadaan lembaga pembiayaan syariah, sumber daya manusia (SDM), serta sosialisasinya. Sebagai lembaga yang relatif baru, pangsa dan volume lembaga pembiayaan syariah belum begitu besar sehingga akan mempengaruhi kemampuan serta skala prioritas dalam pembiayaan yang dilakukan. ${ }^{23}$

\footnotetext{
${ }^{21}$ Ashari dan Saptana, Prospek Pembiayaan, h. 133.

${ }^{22}$ Ascarya, "Peranan Perbankan Syariah dalam Transmisi Kebijakan Moneter Ganda," dalam Jurnal Ekonomi Islam Republika (26 Agustus 2010), h. 5.

${ }^{23}$ Menurut data Bank Indonesia bulan Januari tahun 2005, total pembiayaan syariah untuk
} 
Demikian juga dari sisi SDM, masih harus disiapkan SDM yang mumpuni dalam bidang pembiayaan syariah sehingga tidak kesulitan pada taraf implementasinya. Selain itu kurang gencarnya sosialisasi tentang lembaga pembiayaan syariah terutama mengenai visi, misi, maupun produk yang ditawarkan juga menjadi kendala yang dapat menghambat perkembangan model pembiayaan ini. Salah satu tantangan yang cukup serius dan mempengaruhi operasional perbankan syariah dalam pembiayaan usaha adalah ketidaksesuaian antara aturan syariah dengan aturan yang berlaku dengan hukum positif menimbulkan kesan yang negatif dari kalangan masyarakat luas. Anggapan masyarakat bahwa label-label Islam yang melekat dalam nama bank dan produk-produknya dianggap sebagai suatu strategi untuk membangkitkan emosi keagamaan umat Islam yang dalam realitas praktisnya tidak berbeda dari bank konvensional. ${ }^{24}$

Pada sisi lain, isu sentral yang sering didengar adalah bahwa pemahaman masyarakat mengenai sistem, prinsip pelayanan dan produk perbankan yang berdasarkan syariah Islam sebagian besar masih kurang tepat. Hal demikian bukan hanya terdapat pada masyarakat awam, tetapi juga terjadi pada ulama, kiai dan tokoh masyarakat lainnya. Meskipun sistem ekonomi Islam telah jelas dan mudah dipahami, yaitu melarang menggandakan uang secara tidak produktif dan konsentrasi kekayaan pada satu pihak dan secara tidak adil. Namun secara praktis bentuk produk dan pelayanan jasa, prinsipprinsip dasar hubungan antara bank dengan nasabah, serta cara-cara berusaha yang halal dalam bank syariah masih terasa awam dan belum dipahami secara benar.

Sebagai sebuah bank yang didasarkan kepada syariah Islam, perbankan syariah dalam opersionalnya harus tunduk kepada hukum yang berlaku. Bank Islam sebagai bank komersial yang merupakan bagian integral dari sistem perbankan di Indonesia harus tunduk pada hukum atau aturan-aturan yang ditetapkan oleh pemerintah dan Bank Indonesia. ${ }^{25}$

Pengetahuan dan persepsi yang positif dari pihak perbankan syariah terhadap sektor pertanian akan mendorong perbankan untuk memberikan alokasi kredit yang memadai pada sektor pertanian atau sebaliknya. Di sisi lain pengetahuan dan persepsi pelaku usaha pertanian terhadap perbankan syariah akan menentukan perilaku para pelaku usaha pertanian. Ada beberapa dugaan sebab kelambanan pertumbuhan bank syariah saat ini, di antaranya adalah penerapan aturan kehati-hatian (prudential) pada bank syariah yang sama dengan yang diterapkan pada perbankan konvensional. Padahal, bank syariah pada prinsipnya harus bersedia menanggung resiko pembiayaan yang tinggi karena mengandalkan akad bagi hasil. Dipaksa oleh aturan kehati-hatian yang ketat, bank syariah

sektor pertanian sebesar Rp. 851,7 milyar atau sekitar 7,3 \% dari seluruh pembiayaan yang telah disalurkan.

${ }^{24}$ Muhammad, Lembaga Ekonomi Syariah (Yogyakarta: Graha Ilmu, 2007), h. 31.

${ }^{25}$ Akhmad Mujahidin, "Penguatan Usaha Ekonomi Umat Melalui Perbankan Syariah", Makalah disampaikan pada Annual Conference on Islamic Studies (ACIS) Ke-10, Banjarmasin, 1-4 November 2010. 
pada praktiknya lebih banyak menggunakan akad jual beli yang mirip dengan kredit konvensional. Kemiripan ini menimbulkan masalah kedua di atas, di mana masyarakat yang peduli syariah menjadi tidak peduli terhadap bank syariah. ${ }^{26}$

\section{Faktor Strategi Peningkatan Peranan Bank Syariah untuk Pembiayaan Usaha Pertanian}

Berdasarkan uraian karakteristik, kekuatan dan kelemahan serta peluang dan tantangan peningkan peranan bank syariah untuk pembiayaan usaha pertanian di atas, maka ditemukan faktor strategi internal, yaitu: (1) Adanya dukungan Bank Indonesia untuk mengembangkan bank syariah, (2) Peranan bank syariah cukup besar dalam pembangunan ekonomi, (3) Prinsip pembiayaan syariah dapat meningkatkan usaha pertanian, (4) Tingkat keuntungan yang sangat tinggi dari bisnis bank syariah, (5) Letak bank syariah masih terpusat pada kota-kota besar yang jauh dari lokasi usaha pertanian, (6) Pembiayaan bank syariah belum banyak menyentuh usaha pertanian, (7) Usaha pertanian skala kecil umumnya tidak memiliki badan hukum, (8) Kepercayaan pihak bank syariah untuk pembiayaan usaha pertanian rendah karena usaha ini memliki resiko kerugian yang lebih besar dibanding dengan usaha lain.

Manakala faktor eksternal yang akan mempengaruhi strategi peningkan peranan bank syariah untuk pembiayaan usaha pertanian antara lain: (1) Banyaknya produk pembiayaan bank syariah yang sesuai untuk pembiayaan usaha pertanian, (2) Respons masyarakat terhadap bank sangat besar, (3) Peluang pasar bank syariah lebih luas dibanding pasar bank konvensional, (4) Bank Syariah lebih mampu menjembatani sector riil karena fungsi intermediasi yang lebih baik (FDR konsisten mendekati 100\%), (5) Peraturan Perbankan yang berlaku belum sepenuhnya mengakomodasi operasional bank syariah, (6) Pemahaman masyarakat yang belum tepat terhadap bank syariah, (7) Sedikit sumber daya manusia yang memiliki keahlian dalam bank syariah, (8) Pembiayaan usaha pertanian tidak akan mendapat dukungan kredit dalam jumlah sesuai dengan kebutuhan.

\section{Strategi Peningkatan Peranan Bank Syariah untuk Pembiayaan Usaha Pertanian}

Peranan bank syariah dapat ditingkatkan dengan menggunakan kekuatan untuk mengatasi kelemahan dan menggunakan peluang untuk meminilisasi tantangan, khususnya untuk pembiayaan usaha pertanian di Indonesia. Berdasarkan pertimbangan tersebut, maka upaya meningkatkan peranan bank syariah untuk pembiayaan usaha pertanian

${ }^{26}$ Muhamad Said Fathurrohman. "Memacu Pertumbuhan Bank Syariah", http://ekisopini. blogspot.com/2009/12/memacu-pertumbuhan-bank-syariah.html diunduh pada tanggal 26 Desember 2010. 
menggunakan strategi sebagai berikut: Pertama, mengembangkan kantor bank syariah pada daerah pertanian. Kedua, memberikan pembiayaan syariah seperti al-Muzâra'ah (Harverst-Yield Profit Sharing), Bai' al-salâm (in front payment sale); Bai' al-murâbahah (differed payment sale), dan al-Rahn. Ketiga, melakukan pemasaran produk pembiayaan bank syariah kepada usaha pertanian terutama yang memiliki prospek pasar yang cukup besar. Keempat, melakukan pemasaran produk pembiayaan bank syariah kepada usaha pertanian yang dilakukan kelompok tani atau gabungan kelompok tani andalan. Kelima, memberikan pembiayaan bank syariah yang sesuai dengan usaha pertanian secara penuh, agar potensi kegagalan panen dapat diminimalisir. Hal ini didasarkan mengapa Rasulullah SAW. membolehkan Bai' al-salâm adalah karena beliau menyadari bahwa petani sangat bergantung pada permodalan. Karena itu, sudah saatnya skema-skema pembiayaan pertanian berbasis syariah harus terus didorong dan ditingkatkan. Jika perlu, pemerintah menerbitkan sukuk berbasis akad salam sebagai pintu investasi di sektor pertanian.

\section{Penutup}

Prinsip dan jenis pembiayaan bank syariah banyak yang sesuai untuk mengatasi masalah pembiayaan usaha pertanian. Selama ini usaha pertanian di daerah pedesaan untuk memenuhi kebutuhan akan modal usaha terutama untuk memenuhi kebutuhan akan sarana produksi seperti benih, pupuk, dan pestisida, petani memperoleh dengan cara berhutang kepada kios penjual sarana produksi dan akan dibayar dengan menjual hasil panen kepada pemilik kios sesuai dengan jumlah dan harga yang disepakati. Fakta ini lazim dijumpai pada daerah pedesaan. Peluang ini dapat dipenuhi dengan pembiayaan Bai' al-salâm.

Bank syariah mempunyai peranan yang sangat penting untuk mendukung pembangunan nasional, khususnya pembangunan pertanian. Sektor pertanian merupakan sumber mata pencaharian sebahagian besar penduduk Indonesia. Sudah selayaknya bank syariah dapat berperan lebih dalam meningkatkan kesejahteraan masyarakat, terutama untuk mengentaskan kemiskinan. Ajaran Islam sangat menekankan urgensi keberpihakan kepada masyarakat kecil. Dalam sebuah hadis, Rasulullah SAW. bersabda "Kalian akan ditolong dan diberi rezeki dengan sebab (kalian menolong) kaum dhuafa' di antara kalian."

Peranan bank syariah untuk pembiayaan usaha pertanian dapat ditingkatkan dengan menggunakan strategi: (1) Mengembangkan kantor bank syariah pada daerah pertanian. (2) Memberikan pembiayaan syariah yang lebih besar kepada usaha pertanian. (3) Melakukan pemasaran produk pembiayaan bank syariah kepada usaha pertanian. (4) Memberikan pembiayaan bank syariah yang sesuai dengan usaha pertanian secara penuh, agar potensi kegagalan panen dapat diminimalisir. 


\section{Pustaka Acuan}

Agustianto, "Pemberdayaan Agribisnis Melalui Bank Syari'ah,” dalam http://agustianto. niriah.com/2008/04/04/pemberdayaan-agribisnis-melalui-bank-syari'ah/ diunduh pada tanggal 26 Desember 2010.

Antonio, Muhammad Syafi'i. Bank Syariah dari Teori ke Praktik. Jakarta: Gema Insani, 2001.

Ascarya. "Peranan Perbankan Syariah dalam Transmisi Kebijakan Moneter Ganda," dalam Jurnal Ekonomi Islam Republika, 26 Agustus 2010.

Ashari. "Peran Perbankan Nasional dalam Pembiayaan Sektor Pertanian di Indonesia," dalam Forum Penelitian Agro Ekonomi, vol. XXVII, No. 1, Juli 2009.

Ashari dan Saptana. "Prospek Pembiayaan Syariah Untuk Sektor Pertanian," dalam Forum Penelitian Agro Ekonomi, vol. XXIII, No. 2, Desember 2005.

Arifin, Bustanul. "Mengatasi Kesulitan Pembiayaan Sektor Pertanian," http://barifin.multiply. com/journal/item/17?\&item id=17\&view:replies=reverse diunduh pada tanggal 20 Desember 2010.

Fathurrohman, Muhamad Said. Memacu Pertumbuhan Bank Syariah, http://ekisopini.blogspot. com/2009/12/memacu-pertumbuhan-bank-syariah.html diunduh pada tanggal 26 Desember 2010.

Hayati, Neuneung Ratna. "Perbankan Syariah Nasional: Peranan, Peluang, Permasalahan, Prospek Serta Strategi Pengembangannya," dalam Jurnal Bisnis, Manajemen dan Ekonomi, vol. VII, No. 3, Februari 2006.

Hafidhuddin, Didin. "Pertanian dengan Prinsip Syariah," dalam http://www.hdrfarm. $\underline{\mathrm{com} / ? \mathrm{p}=219}$, diunduh pada tanggal 20 Desember 2010.

Muhammad, Bank Syari'ah Problema dan Prospek Perkembangan di Indonesia, Yogyakarta: Graha Ilmu, 2005.

Mujahidin, Akhmad. "Penguatan Usaha Ekonomi Umat Melalui Perbankan Syariah," Makalah disampaikan pada Annual Conference on Islamic Studies (ACIS) Ke-10, Banjarmasin, 1-4 November 2010.

Rochma, Malia. “Perbankan Syariah: Peluang dan Strategi Pengembangan,” http://ucupneptune. blogspot.com/2007/11/perbankan-syariah-peluang-dan strategi.html diunduh pada tanggal 24 Desember 2010.

Supriatna, Ade. "Pola Pelayanan Pembiayaan Sistem Kredit Mikro Usaha Tani di Tingkat Pedesaan," dalam Jurnal Litbang Pertanian, 28 Februari 2009. 